\title{
Gender diversity and computational independency
}

\author{
Pedro D. A. Mendes*, Victória V. Celeri.
}

\begin{abstract}
Engineering courses suffer from a large gender gap among faculty, students, and practitioners. Women are a minority in STEM (Science, technology, engineering, mathematics) courses, but in pre-Universitary education both boys and girls have in common the lack of opportunities to learn programming skills. In this project, we research teaching methods and experiences (both local and international) to improve logical thinking, and gender diversity in High School to alleviate those issues.
\end{abstract}

\section{Key words:}

Gender, diversity, education.

\section{Introduction}

In this project we analyzed a vast number of initiatives to incentivize the interest of teenagers for computation. As any other basic skill, such as cooking, reading, writing, driving, computational skills open many opportunities. Someone who understands logic thinking and programming skills has a clear competitive advantage to solve day-to-day problems ${ }^{1}$, or even major societal issues, enjoying increased independency. However, we face challenges in providing those skills: most teenagers do not have any contact at all with those skills, and, in addition, we face a large gender gap in STEM areas.

Our project focuses in creating a programming course to guide students, teachers, and organizations in providing those skills. We are creating a free, open material that fosters diversity. We based our material in the MIT App Inventor ${ }^{2}$ platform, which has been proved very effective for teaching teenagers, due to the easy visual language it employs, and its target to mobile device.

\section{Results and Discussion}

The production of this courseware took into consideration teenagers' current interests, situation of Brazil's public schools, the versatility of MIT App Inventor's platform and, of course, gender diversity issues, to guide us as we created the material. Our goal was to implement a scaffolding ${ }^{3}$ teaching technique, in which the answers were not just bluntly given away. We wanted to encourage students in the pursuit of answers while creating apps that interested them such as social medias, messaging groups, games, and others. As a result of the scaffolding technique we prepared scripts to then film short videos, which together will constitute learning paths.

Along with the short videos, the core of this project is the courseware that will be released for free on the Internet. It will be available as three volumes aimed at students, teachers, and organizers (who may or may not be the teachers). The students' volume will include the routine of each lesson with tips, exercises, challenges and links. The teacher's volume will also include the routine of each class, but with specific tips related to solutions to problems that may occur during the lesson, and other helpful pedagogical information that we extracted from the various researches regarding the problems faced in classroom. Those include gender issues that often result in making the area less atractive to girls, but also behavior of the students, suggestions for assistants, and other classroom issues.

The organizer's volume is the main material, where we explain in detail how to organize the programming course for beginners. This volume focuses on practical issues the organizer needs to address to create the course, ranging from ensuring there are enough power outlets, until checking the course timetable is compatible with the availability of the targeted students.

\section{Conclusions}

Using MIT App Inventor favors teaching teenagers since creating apps for smartphones gives them a very concrete incentive, related to something present in their daily live, and something they already love. Logical thinking and programming are not rocket science and should be available to anyone interested, just like Math, History, Geography, and other basic subjects.

\footnotetext{
${ }_{1}^{1}$ Morrison, N. Teach kids how to code and you give them a skill for life. Forbes. 2013 [cited 2013 Dec 27] Available from: https://www.forbes.com/sites/nickmorrison/2013/12/27/teach-kids-how-tocode-and-you-give-them-a-skill-for-life/2/\#64d6c15069cf

${ }^{2}$ Gomes, Tancicleide CS, and Jeane CB de Melo. "App inventor for android: Uma nova possibilidade para o ensino de lógica de programaçao." Anais dos Workshops do Congresso Brasileiro de Informática na Educação. Vol. 2. No. 1. 2013.

${ }^{3}$ Van de Pol, J., Volman, M., \& Beishuizen, J. (2010). Scaffolding in teacher-student interaction: A decade of research. Educational psychology review, 22(3), 271-296.
} 